\title{
On the genus Pachygnatha (Araneae, Tetragnathidae) in the Albertine Rift of Burundi, with the description of three new species
}

\author{
Benoît NZIGIDAHERA ${ }^{1}$ \& Rudy JOCQUÉ ${ }^{2}$ \\ ${ }^{1}$ Institut National pour l'Environnement et la Conservation de la Nature, B.P. 2757 Bujumbura, Burundi \\ ${ }^{2}$ Royal Museum for Central Africa, B-3080 Tervuren, Belgium \\ Email: rudy.jocque@africamuseum.be (corresponding author) \\ ${ }^{1}$ urn:Isid:zoobank.org:author:3112C6AF-BB9B-4CF7-B0A6-A709D2473A25 \\ ${ }^{2}$ urn:lsid:zoobank.org:author:CF15016C-8CD1-4C9D-9021-44CA7DC7A5D5
}

\begin{abstract}
Three new species of Pachygnatha, $P$. bispiralis sp. nov., $P$. intermedia sp. nov. and $P$. ventricosa sp. nov., are described from forest areas in western Burundi. The presence of $P$. procincta Bosmans \& Bosselaers, 1994 in Burundi confirms its very wide distribution spanning most of Africa. Pachygnatha appears to be an important element of the afromontane spider fauna.
\end{abstract}

Keywords. Kibira National Park, Afromontane forest, new species, genus template, biodiversity hotspot.

Nzigidahera B. \& Jocqué R. 2014. On the genus Pachygnatha (Araneae, Tetragnathidae) in the Albertine Rift of Burundi, with the description of three new species. European Journal of Taxonomy 93: 1-16. http://dx.doi. org/10.5852/ejt.2014.93

\section{Introduction}

Twelve species of Pachygnatha Sundevall, 1823 are known from tropical Africa (Platnick 2014). Bosmans \& Bosselaers (1994) gave an excellent overview of this fauna and not only described several new species from Cameroon but also redescribed all known species except one, P. africana Strand, 1906 for which the types could not be traced, doubtless because they have been destroyed during World War II (Renner 1988).

Of the twelve species, two are known from Central Africa, and more precisely from mountainous areas in the Albertine Rift: Pachygnatha kiwuana Strand, 1913, and Pachygnatha ruanda Strand, 1913.

During three years $(2003,2004-2005,2008)$ of field work along altitudinal gradients (793 to $2650 \mathrm{~m}$ ) in the afromontane forest of Kibira, miombo forest of Rumonge and circum-Guinean forest of Kigwena, four species of Pachygnatha have been found. Only Pachygnatha procincta Bosmans \& Bosselaers, 1994 has been previously described. It apparently has a wide distribution and was known from Cameroon and Kenya. Three other species are here described as new.

\section{Material and methods}

Primary types are deposited in the Musée Royal de l'Afrique Centrale, Tervuren, Belgium (MRAC), whereas paratypes are divided among MRAC and the Institut National pour l'Environnement et 
la Conservation de la Nature, Bujumbura, Burundi (INECN). Specimens were observed, drawn and measured with a WILD M 10 stereo microscope. Details of the female genitalia and male palps were observed with a Zeiss Stemi 2000 strereo microscope.

Female genitalia were detached from the abdomen, cleared with methyl salicylate and temporarily mounted in a mixture of methyl salicylate and cedukol for examination. The same method was used to observe details of the male palp. These structures were photographed with a Leica MZ16 stereo microscope and subject to automontage with the Syncroscopy software. All measurements are in $\mathrm{mm}$. As with the illustrations, they were taken from the holotype and paratypes unless stated otherwise. Coordinates are in decimal format. The distribution map for Pachygnatha procincta (Fig. 6) shows only one spot in Burundi: it covers both the adjacent collection sites Kibira and Kigwena mentioned in this paper and of which the former is the type locality of the three new species.

\title{
Abbreviations
}

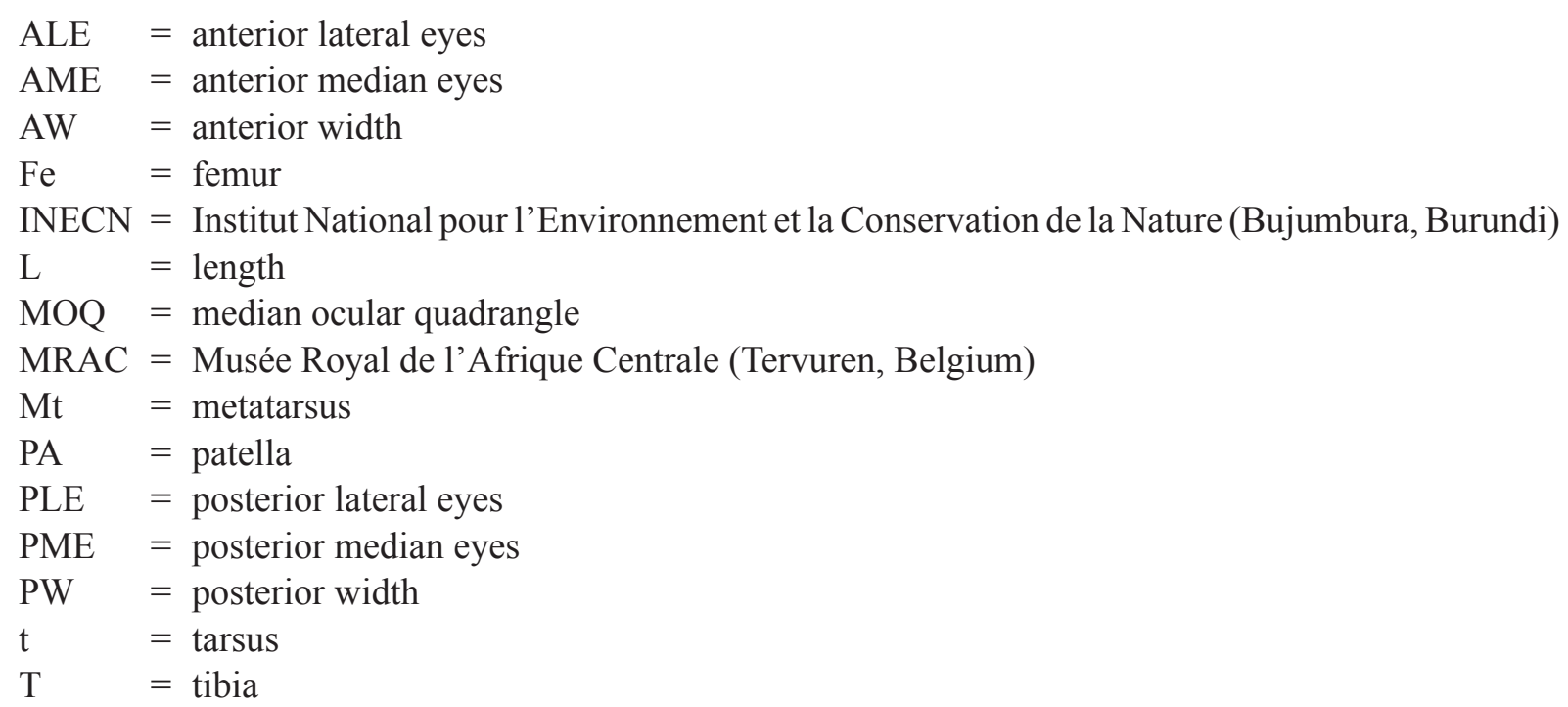

\section{Results}

\author{
Class Arachnida Cuvier, 1812 \\ Order Araneae Clerck, 1757 \\ Family Tetragnathidae Menge, 1866 \\ Genus Pachygnatha Sundevall, 1823 \\ Pachygnatha bispiralis sp. nov. \\ urn:1sid:zoobank.org:act:E6CDD3F2-0E67-4520-A794-E5D48E37EFC8
}

Figs $1 \mathrm{~A}-\mathrm{C}, 2 \mathrm{~A}-\mathrm{D}$

\section{Diagnosis}

Males are easily recognized by several unique features: the peculiar cymbium which is strongly narrowed at the mid-point, the very long conductor protruding beyond the cymbium, the tibia with a large ventrolateral apophysis and the very large, claw shaped, distal spur on the chelicerae.

\section{Etymology}

The specific name bispiralis refers to the broad embolus with longitudinal groove giving the impression of a sclerite with two spirals. 
NZIGIDAHERA B. \& JOCQUÉ R., New Pachygnatha species (Araneae, Tetragnathidae) from Burundi

\section{Type material examined}

\section{Holotype}

BURUNDI: $\widehat{\partial}$, Kibira National Park, Rwegura, Mt Musumba, $02.87696^{\circ} \mathrm{S}, 029.49709^{\circ} \mathrm{E}$, site 1 , mountain heather with Philippia benguelensis, 10 Mar. 2008, 2650 m, pitfalls, B. Nzigidahera (MRAC 226712).

\section{Paratypes}

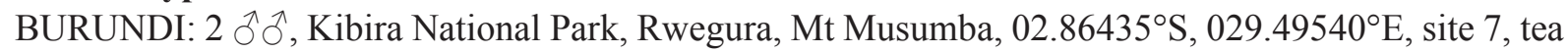
plantation, 10 Sep. $2008,2100 \mathrm{~m}$, pitfalls, B. Nzigidahera (INECN); 1 ô, same locality, $02.86435^{\circ} \mathrm{S}$, 029.49546 ${ }^{\circ} \mathrm{E}$, site 6, forest with Carapa grandiflora and Polyscias fulva, 25 Mar. 2008, $2150 \mathrm{~m}$ (MRAC 226711); 1 §, 1 juv., same locality, 10 Mar. 2008 (MRAC 226730); 1 o, same locality, $02.86445^{\circ} \mathrm{S}$, $029.49640^{\circ} \mathrm{E}$, site 5, forest with Carapa grandiflora and Polyscias fulva, $25 \mathrm{Jul} .2008,2252 \mathrm{~m}$ (MRAC 226722); 1 ð̊, same locality, 10 Apr. 2008 (MRAC 226724); 1 ô, same locality, 25 Feb. 2008 (MRAC

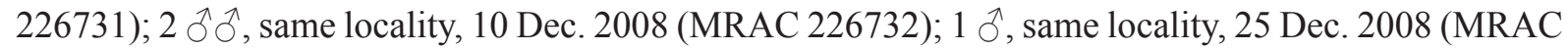

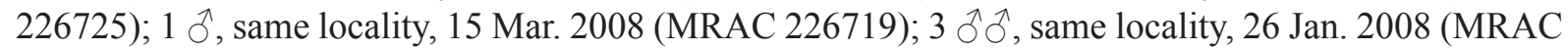
226721); $1 \mathrm{O}^{\top}$, same locality, $02.87149^{\circ} \mathrm{S}, 029.49641^{\circ} \mathrm{E}$, site 3, forest with Hagenia abyssinica, $25 \mathrm{Apr}$.

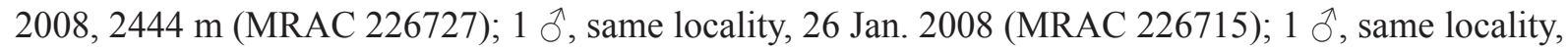

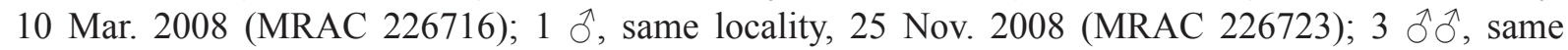
locality, 25 Feb. 2008 (MRAC 226720); 1 đ, same locality, 10 Nov. 2008 (INECN); 1 đ, same locality, $02.87060^{\circ} \mathrm{S}, 029.49669^{\circ} \mathrm{E}$, site 2 , forest with Hagenia abyssinica, 25 Apr. 2008, $2548 \mathrm{~m}$ (INECN); $1 \mathrm{O}$, same locality, $02.87696^{\circ} \mathrm{S}, 029.49709^{\circ} \mathrm{E}$, site 1 , forest mountain heather, Phillipia benguelensis,

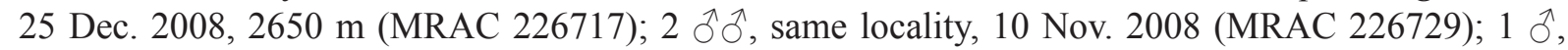

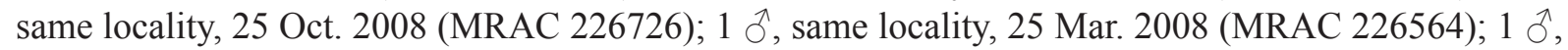
same locality, 25 Jun. 2008 (INECN); 1 o, same locality, 10 Sep. 2008 (INECN); 1 ô, same locality, $25 \mathrm{Feb} .2008$ (INECN); $1 \partial^{\lambda}$, same locality, $0289891^{\circ} \mathrm{S}, 02950405^{\circ} \mathrm{E}$, site 1 , tea plantation, 15 May 2005, $1970 \mathrm{~m}$ (INECN); 1 §, Kibira National Park, Rusarenda Forest, $03.14228^{\circ} \mathrm{S}, 029.56235^{\circ} \mathrm{E}$, forest with Neoboutonia macrocalyx and Myrianthus holstii, 12 Feb. 2003, 2237 m, pitfalls, B. Nzigidahera (INECN); 1 ô, Kigwena Nature Reserve, Kigwena Forest, $02.89891^{\circ} \mathrm{S}, 029.50405^{\circ} \mathrm{E}$, forest with Newtonia buchananii and Albizia zygia, 5 Jan. 2004, 793 m, pitfalls, B. Nzigidahera (INECN).

\section{Description}

Male

Holotype, Figs 1A-C, 2A-D.

MeAsurements. Total length 2.70, carapace 1.20 long, 1.08 wide.

CARAPACE. Pale brown, with two lateral dark brown bands; prominent in anterior part.

Eyes. AME: 0.12, ALE: 0.12, PLE: 0.12, PME: 0.20, AME-AME: 0.02, PME-PME: 0.02, AME-ALE: 0.04, PME-PLE: 0.06, ALE-PLE: 0.00, MOQ: AW: 0.26, PW: 0.32, L: 0.32.

Chelicerae. (Fig. 2C-D). Four promarginal teeth, four retromarginal teeth, large claw shaped prolateral spur with broad base and sharp, curved tip.

Sternum. Brownish grey with some setae, distal margin concave; intercoxal sclerites present.

LEGS. Yellowish brown; one distal dorsal spine on patellae; no further spines.

AвDOMEN. Yellowish grey with irregular, connected dark grey spots in almost three longitudinal lines, mixed with silvery spots. Spinnerets pale yellow. 

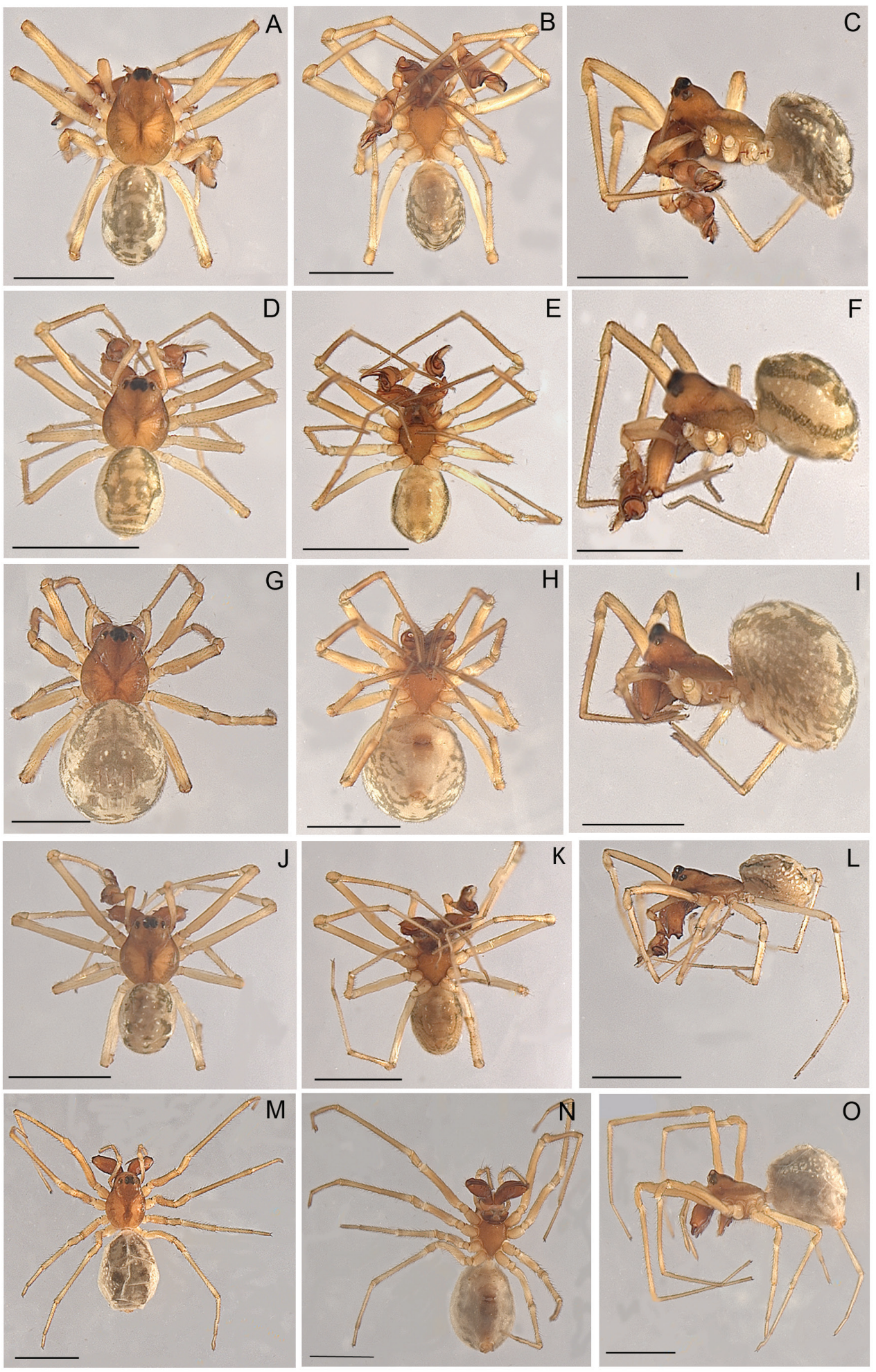

Fig. 1. A-C. Pachygnatha bispiralis sp. nov. A. Male habitus, dorsal view. B. Male habitus, ventral view. C. Male habitus, lateral view. D-I. Pachygnatha intermedia sp. nov. D. Male habitus, dorsal view. E. Male habitus, ventral view. F. Male habitus, lateral view. G. Female habitus, dorsal view. H. Female habitus, ventral view. I. Female habitus, lateral view. J-O. Pachygnatha ventricosa sp. nov. J. Male habitus, dorsal view. K. Male habitus, ventral view. L. Male habitus, lateral view. M. Female habitus, dorsal view. N. Female habitus, ventral view. O. Female habitus, lateral view. Scale bars $=2 \mathrm{~mm}$. 
PALP. (Fig. 2A-B). Sclerotised tibial apophysis very broad, large blade-shape retrolaterally high, ventrally short. Paracymbium long, straight with some long hairs at the sharp, slightly curved tip. Cymbium very broad at base, thin in middle and wider towards tip. Embolus long, running along tegulum and beyond to tip of cymbium, supported by conductor.

LEG MEASUREMENTS

\begin{tabular}{|c|c|c|c|c|c|c|}
\hline Leg & $\mathbf{F e}$ & $\mathbf{P a}$ & $\mathbf{T}$ & $\mathbf{M t}$ & $\mathbf{t}$ & Total \\
\hline I & 1.64 & 0.48 & 1.76 & 1.44 & 0.80 & 6.12 \\
\hline II & 1.60 & 0.44 & 1.96 & 1.28 & 1.76 & 7.04 \\
\hline III & 1.20 & 0.40 & 0.92 & 0.88 & 0.48 & 3.88 \\
\hline IV & 1.48 & 0.40 & 1.40 & 1.28 & 0.64 & 5.20 \\
\hline
\end{tabular}

\section{Female}

Unknown.

\section{Distribution}

Known from Kibira National Park and Kigwena Nature Reserve in Burundi.

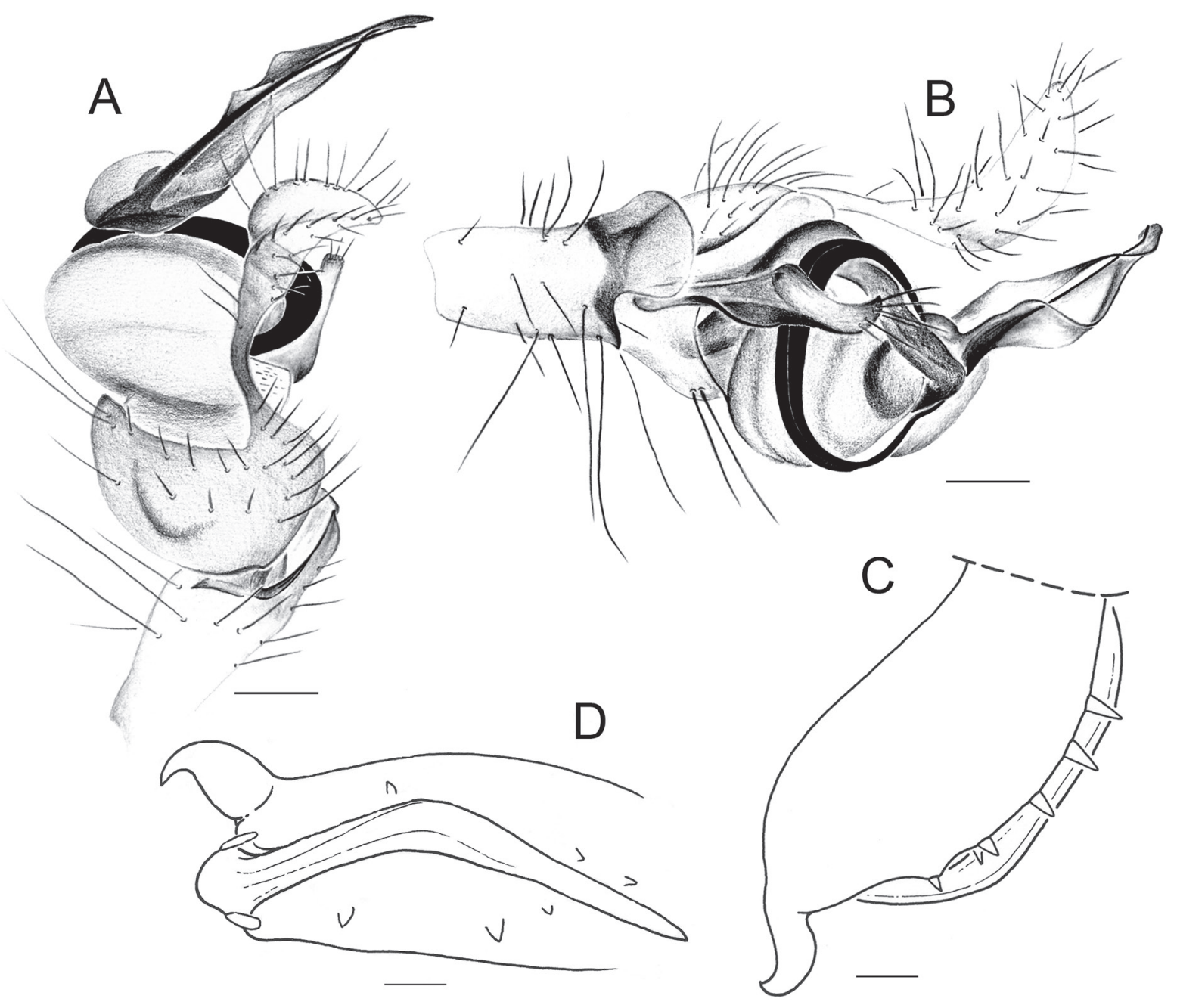

Fig. 2. Pachygnatha bispiralis sp. nov. A. Male left palp, dorsal view. B. Male palp, retrolateral view. C. Male right chelicera, frontal view. D. Male right chelicera, ventral view. Scale bars $=0.1 \mathrm{~mm}$. 


\section{Pachygnatha intermedia sp. nov. \\ urn:Isid:zoobank.org:act:AE150829-001F-4063-94A1-86FDA88B309D}

Figs 1D-I, 3A-H, 5A

\section{Diagnosis}

Males are recognized by details of the palp: the cymbium is unique in having a central membranous area dividing it into a proximal and a distal part, the latter provided with a short, thin prong; the paracymbium is broad at its base with a retrolateral swelling and a triangular prolateral extension, the distal part is slender and tapered to a point; the tibia has a well developed truncate dorsal apophysis. The female is recognized by the rectangular sclerotised areas in front and behind the genital opening.

P. intermedia sp. nov. is closely related to P. okuensis Bosmans \& Bosselaers, 1994. The males share the distal paracymbial excavation, the shape of the cheliceral fang and the lozenge shaped paracymbium. Both the latter differ in details of the shape: in P. intermedia the triangular extension of the cheliceral fang is much more pronounced and the distal prong of the paracymbium is much more slender and longer; the excavation of the cymbium is subdistal whereas it is at the distal tip of P. okuensis. The female has a cheliceral spur on the promargin of the chelicerae. With $P$. goedeli Bosmans \& Bosselaers, 1994 it shares the paracymbium with long narrow distal extension and the small cymbial distal prong but details of these sclerites are clearly different.

\section{Etymology}

The specific name intermedia refers to shape of the paracymbium which is of median size in between the very broad paracymbium of Pachygnatha ventricosa sp. nov. and the narrow one of P. bispiralis sp. nov.

\section{Type material examined}

\section{Holotype}

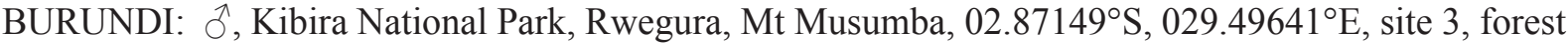
with Hagenia abyssinica, 10 Jul. 2008, 2444 m, pitfalls, B. Nzigidahera (MRAC 226552).

\section{Paratypes}

BURUNDI: 1 क, Kibira National Park, Rwegura, Mt Musumba (same locality for all paratypes), $02.86435^{\circ} \mathrm{S}, 029.49540^{\circ} \mathrm{E}$, site 7 , tea plantation, 10 Dec. $2008,2100 \mathrm{~m}$, pitfalls, B. Nzigidahera (MRAC 226772); 1 §, 25 Feb. 2008 (INECN); 1 ㅇ, 25 Oct. 2008 (INECN); 1 ô, $02.86435^{\circ} \mathrm{S}, 029.49546^{\circ} \mathrm{E}$, site

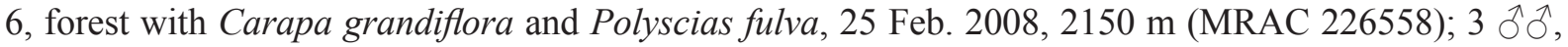
25 Jul. 2008 (MRAC 226562); $1 \overbrace{}^{\Uparrow}, 10$ Nov. 2008 (INECN); 3 우, $02.86445^{\circ} \mathrm{S}, 029.49640^{\circ} \mathrm{E}$, site 5, forest with Carapa grandiflora and Polyscias fulva, 25 Apr. 2008, 2252 m (MRAC 226747); 1 ô, 25 Jul. 2008

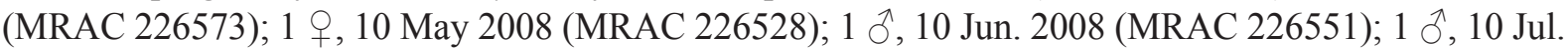
2008 (MRAC 226548); $1 \mathrm{O}^{\mathrm{O}}, 02.86455^{\circ} \mathrm{S}, 029.50427^{\circ} \mathrm{E}$, site 4 , forest with Macaranga neomildbraediana and Polyscias fulva, 10 Oct. 2008, $2352 \mathrm{~m}$ (MRAC 226735); 2 §े ${ }^{2}, 25$ Mar. 2008 (MRAC 226554); 1 q, 25 May 2008 (MRAC 226543); 2 우, 25 Sep. 2008 (MRAC 226535); 2 우, 25 Mar. 2008 (MRAC

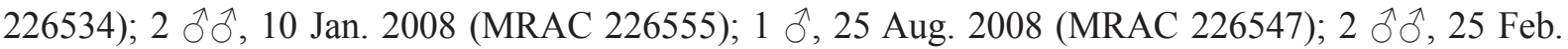
2008 (MRAC 226571); 1 , 25 Sep. 2008 (MRAC 226527); 1 o, 10 Dec. 2008 (INECN); 1 o, 25 Apr.

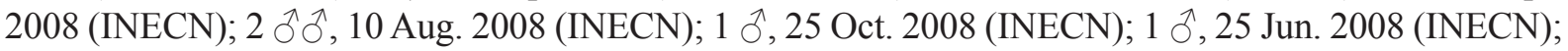
3 우, 25 Jul. 2008 (INECN); 1 + , 25 Dec. 2008 (INECN); 1 ㅇ, 10 Sep. 2008 (INECN); 2 우, 10 Apr. 2008 (INECN); $3 \widehat{\partial}^{\lambda}, 02.87149^{\circ} \mathrm{S}, 029.49641^{\circ} \mathrm{E}$, site 3, forest with Hagenia abyssinica, 25 Nov. 2008, 2444 m (MRAC 226566); 1 §ै, 10 Jul. 2008 (MRAC 226552); 1 , 25 Dec. 2008 (MRAC 226544);

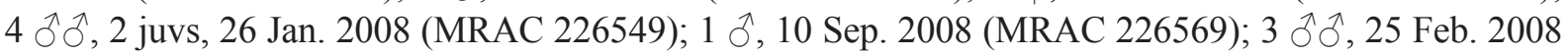
(MRAC 226561); 1 , 10 Apr. 2008 (MRAC 226524); 1 ô, 25 Jun. 2008 (MRAC 226563); 1 ô, 10 Dec. 2008 (MRAC 226556); 1 ठึ, 10 Oct. 2008 (INECN); 2 q,+ 10 Feb. 2008 (INECN); 1 , 26 Jan. 2008 
(INECN); 4 우, 10 Mar. 2008 (INECN); 1 ภ, 10 Feb. 2008 (INECN); 2 $\partial^{\lambda}, 02.87060^{\circ} \mathrm{S}, 029.49669^{\circ} \mathrm{E}$,

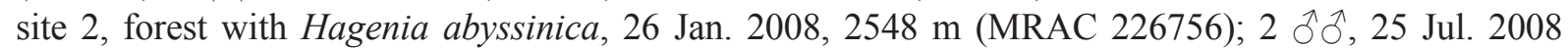

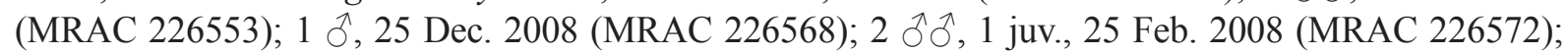
1 今, 10 Aug. 2008 (INECN); 2 ㅇ $, 02.87696^{\circ} \mathrm{S}, 029.49709^{\circ} \mathrm{E}$, site 1 , forest mountain heather, Phillipia benguelensis, 10 Mar. 2008, 2650 m (MRAC 226539); 1 §, 10 May 2008 (MRAC 226567); 1 o, 10 Apr. 2008 (MRAC 226559); 1 đ, 10 Jun. 2008 (MRAC 226557); 3 우, 25 Dec. 2008 (MRAC 226540);

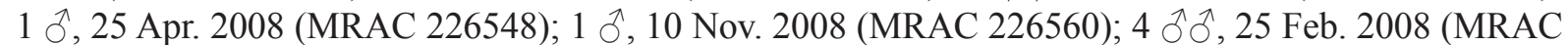

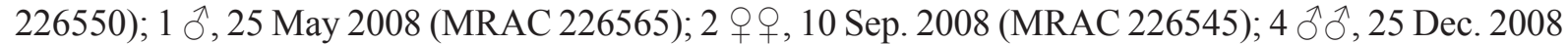

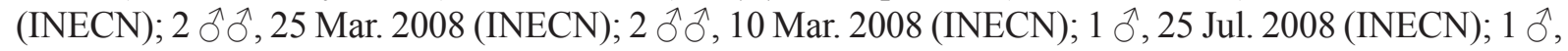
25 Sep. 2008 (INECN); 2 우, 25 Mar. 2008 (INECN); 3 우 ㅇ, 25 Feb. 2008 (INECN).

\section{Description}

Male

Holotype, Figs 1D-F, 3A-D.

MEAsurements. Total length 3.80, carapace 1.90 long, 1.60 wide.

CARAPACE. Brown, with prominent anterior part delimitated by dark brown lines converging in fovea in Y-shape.

Eyes. AME: 0.14, ALE: 0.14, PLE: 0.12, PME: 0.22, AME-AME: 0.04, PME-PME < 0.02, AME-ALE: 0.12, PME-PLE: 0.14, ALE-PLE: 0.00, MOQ: AW: 0.36, PW: 0.40, L: 0.44.

Chelicerae. (Fig. 3C-D). Three promarginal teeth, four retromarginal teeth, with oval spur at tip. Cheliceral fang curved with pronounced triangular extension in the middle.

STERNUM. Brown, with a sharp sclerotised point at each end of the slightly concave anterior margin; intercoxal extensions present.

Legs. Pale yellowish brown with some vague grey spots near femur-patella and tibia-metatarsus articulations; one dorsal distal spine on patellae; no further spines.

ABDomen. Dorsum pale grey with irregular, connected dark grey spots in almost three longitudinal lines, raising a pale area in anterior part; venter pale grey with silvery spots in four longitudinal lines. Spinnerets yellowish grey.

PALP. (Fig. 3A-B). Dorsal tibial apophysis rectangular, retrolateral tibial apophysis oval, sclerotised, with setae, ventral tibial apophysis broad, sclerotised, blade shaped. Paracymbium with lozenge-shaped base and long, slender, distal prong surpassing the tegulum. Cymbium with remarkable membranous central part, with deep subdistal excavation at the tip, delimiting a thin lateral prong with a few setae. Embolus long, broad at the base, thin in middle, slightly widened and with flat, bifid tip; conductor with large, strongly sclerotised, distal part.

LEG MEASUREMENTS

\begin{tabular}{|c|c|c|c|c|c|c|}
\hline Leg & Fe & Pa & T & Mt & t & Total \\
\hline I & 2.24 & 0.60 & 2.28 & 1.80 & 1.80 & 8.72 \\
\hline II & 2.12 & 0.68 & 2.00 & 1.60 & 1.60 & 8.00 \\
\hline III & 1.60 & 0.60 & 1.24 & 1.20 & 1.20 & 5.84 \\
\hline IV & 2.20 & 0.52 & 2.00 & 1.84 & 1.84 & 8.40 \\
\hline
\end{tabular}



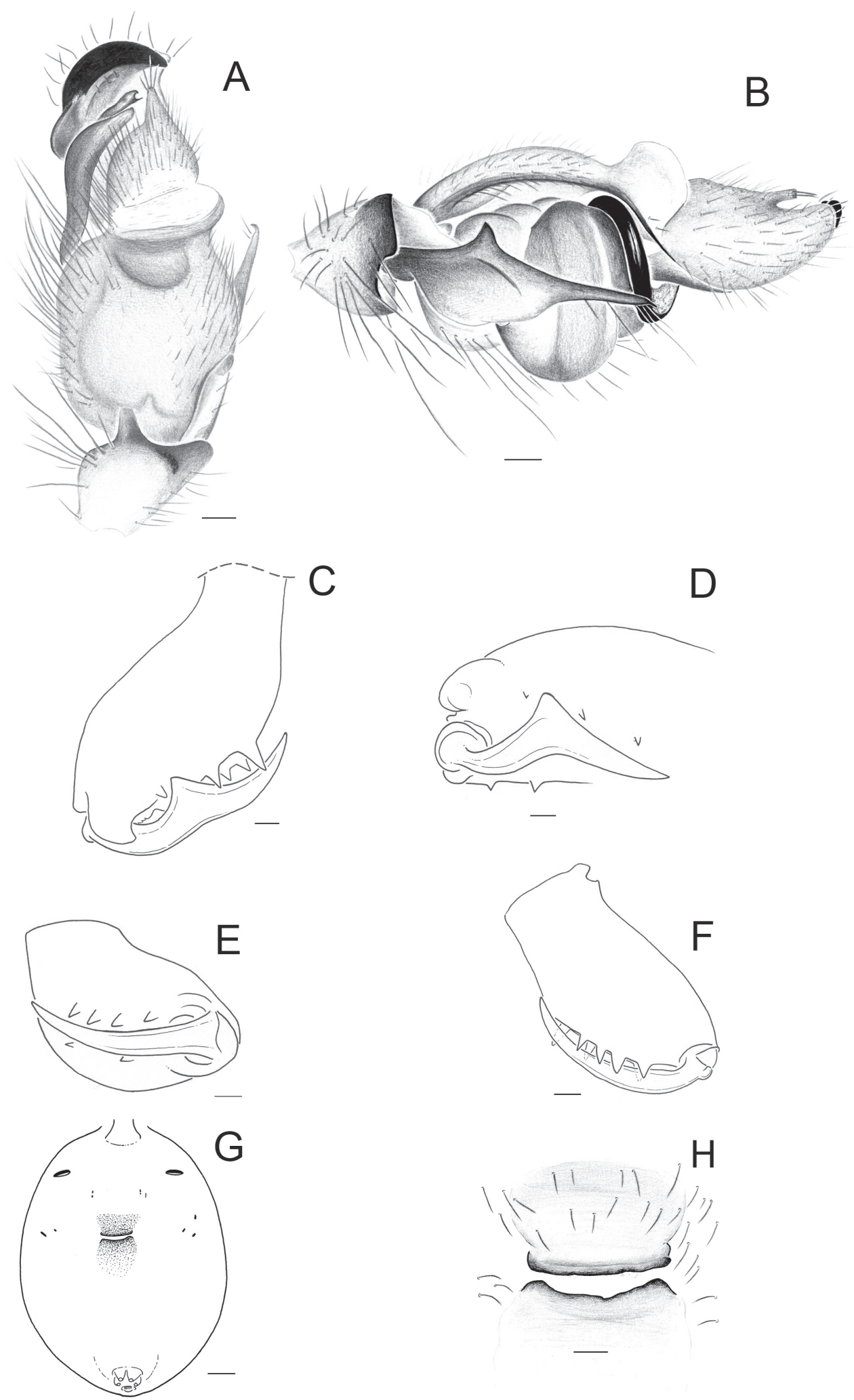

Fig. 3. Pachygnatha intermedia sp. nov. A. Male palp, ventral view. B. Male palp, retrolateral view. C. Male chelicera, frontal view. D. Male chelicera, ventral view. E. Female chelicera, ventral view. F. Female chelicera, frontal view. G. Female abdomen, ventral view. H. Female external genitalia, ventral view. Scale bars: $A-F, H=0.1 \mathrm{~mm} ; G=1 \mathrm{~mm}$. 
NZIGIDAHERA B. \& JOCQUÉ R., New Pachygnatha species (Araneae, Tetragnathidae) from Burundi

\section{Female}

Paratype, MRAC 226544, Figs 1G-I, 3E-H. Very similar to male.

MeAsurements. Total length 4.80. Carapace. 1.92 long, 1.50 wide.

Eyes. AME: 0.14, ALE: 0.16, PME: 0.24, PLE: 014, AME-AME: 0.06, PME-PME < 0.02, ALE-PLE: 0.00, AME-ALE: 0.10, PME-PLE: 0.12; MOQ: AW: 0.44, PW: 0.32, L: 0.44.

Chelicerae. (Fig. 3E-F). Yellowish brown, 3 teeth on promargin and basal spur, 3 teeth on retromargin.

External Genitalia. (Figs 3G-H, 5A). With rectangular sclerotised areas in front of and behind the genital opening.

LEG MEASUREMENTS

\begin{tabular}{|c|c|c|c|c|c|c|}
\hline Leg & Fe & Pa & T & Mt & t & Total \\
\hline I & 1.84 & 0.68 & 1.80 & 1.44 & 0.80 & 6.50 \\
\hline II & 1.80 & 0.68 & 1.60 & 1.40 & 0.76 & 6.24 \\
\hline III & 1.36 & 0.56 & 1.00 & 1.00 & 0.52 & 4.44 \\
\hline IV & 1.96 & 0.52 & 1.68 & 1.60 & 0.64 & 6.40 \\
\hline
\end{tabular}

\section{Other material examined}

BURUNDI: 3 ô $\widehat{\jmath}, 2$ 우, Kibira National Park, Rwegura Forest, $02.89435^{\circ} \mathrm{S}, 029.50078^{\circ} \mathrm{E}$, forest with Maracanga neomildbreadiana and Xymalos monospora, 19 Mar. 2003, 2223 m, pitfalls, B. Nzigidahera

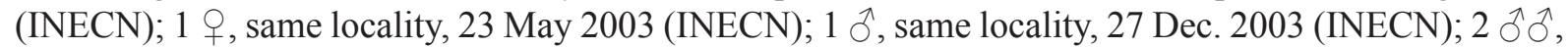
5 우오, same locality, 13 Sep. 2003 (INECN); 1 đ, same locality, 14 Jan. 2004 (INECN); 1 q, Kibira National Park, Rusarenda Forest, $03.14228^{\circ} \mathrm{S}, 029.56235^{\circ} \mathrm{E}$, forest with Neoboutonia macrocalyx and Myrianthus holstii, 12 Feb. 2003, 2237 m, pitfalls, B. Nzigidahera (INECN); 3 đô, 1 q, 1 juv., same locality, 12 Feb. 2003 (INECN); 1 ô, 1 ㅇ, 1 juv., same locality, 21 Mar. 2003 (INECN); 1 q, Kibira National Park, Bugarama Forest, $03.26537^{\circ} \mathrm{S}, 029.54921^{\circ} \mathrm{E}$, forest with Symphonia globulifera and Parinari holstii, 28 Mar. 2003, 2202 m, pitfalls, B. Nzigidahera (INECN); 1 ô, same locality, 14 Oct. 2003 (INECN); 1 ${ }^{\lambda}$, same locality, 15 Jul. 2003 (INECN); 1 O, 1 juv., same locality, 14 Oct. 2003

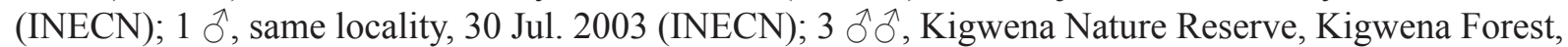
$02.89891^{\circ} \mathrm{S}, 029.50405^{\circ} \mathrm{E}$, forest with Newtonia buchananii and Albizia zygia, 5 Jan. 2004, $793 \mathrm{~m}$, pitfalls, B. Nzigidahera (INECN).

\section{Distribution}

Known from Kibira National Park and Kigwena Nature Reserve in Burundi.

Pachygnatha ventricosa sp. nov. urn:1sid:zoobank.org:act:356C3177-C153-47D7-865B-7FDF1CE821E1

Figs $1 \mathrm{~J}-\mathrm{O}, 4 \mathrm{~A}-\mathrm{H}, 5 \mathrm{~B}$

\section{Diagnosis}

Males of $P$. ventricosa sp. nov. are recognized by details of the palp: the paracymbium has a broad basal part with semicircular retrolateral swelling and small triangular prolateral extension; the cymbium has two parts: a broad basal part, divided from the parallel-sided distal part by a deep, membranous indentation. This resembles that of $P$. bispiralis sp. nov. , but the narrow central part of the cymbium is much longer and not membranous. In Pachygnatha intermedia sp. nov. there is a central membranous cymbial area but the shape of that sclerite is very different. This is somewhat similar to that of $P$. 
kiwuana Strand, 1913 but the distal part of the paracymbium is much longer and well separated from the basal part in $P$. ventricosa sp. nov. Females are characterized by external genitalia with a sclerotised and transverse expansion of the upper lip forming a rectangular shape.

\section{Etymology}

The specific name ventricosa refers to the inflated, belly-shaped lateral part of the paracymbium on the male palp.

\section{Type material examined}

\section{Holotype}

BURUNDI: $\widehat{\jmath}$, Kibira National Park, Rwegura, Mt Musumba, $02.86445^{\circ} \mathrm{S}, 029.49640^{\circ} \mathrm{E}$, site 5 , forest with Carapa grandiflora and Polyscias fulva, 10 Jul. 2008, 2252 m, pitfalls, B. Nzigidahera (MRAC 226777).

\section{Paratypes}

BURUNDI: $1 \hat{\jmath}$, Kibira National Park, Rwegura, Mt Musumba (same locality for all paratypes), $02.86435^{\circ} \mathrm{S}, 029.49540^{\circ} \mathrm{E}$, site 7 , tea plantation, 26 Jan. $2008,2100 \mathrm{~m}$, pitfalls, B. Nzigidahera (INECN); 1 ô, 10 Sep. 2008 (INECN); 1 \%, 25 Apr. 2008 (MRAC 226536); 1 q, $02.86435^{\circ} \mathrm{S}, 029.49546^{\circ} \mathrm{E}$, site 6 , forest with Carapa grandiflora and Polyscias fulva, 26 Jan. 2008, $2150 \mathrm{~m}$ (MRAC 226766); 1 ภ, 25 Dec. 2008 (MRAC 226768); 1 ㅇ, 10 May 2008 (MRAC 226736); 1 ㅇ, 25 Dec. 2008 (MRAC 226748); 1 q, 10 Apr. 2008 (MRAC 226531); 4 q $q, 25$ Aug. 2008 (INECN); 4 qㅜ, 10 Jan. 2008 (INECN); 2 우, 2 juvs: 25 Nov. 2008 (INECN); 1 q, 25 Sep. 2008 (INECN); 3 q $q, 10$ Aug. 2008 (INECN); 1 ô, 2 juvs, $02.86445^{\circ} \mathrm{S}, 029.49640^{\circ} \mathrm{E}$, site 5, forest with Carapa grandiflora and Polyscias fulva, 10 Aug. 2008, $2252 \mathrm{~m}$ (MRAC 227427); 1 ๆ, 2 juvs, 25 Jun. 2008 (MRAC 226775); 1 ô, 10 Sep. 2008 (MRAC

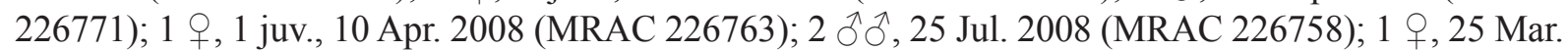

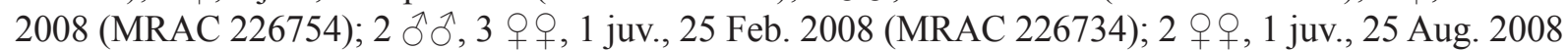

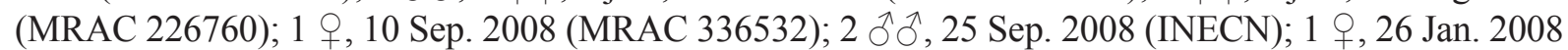

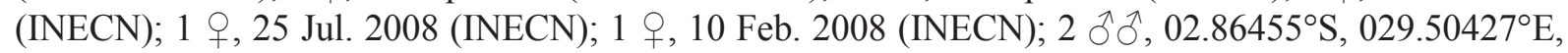
site 4, forest with Macaranga neomildbraediana and Polyscias fulva, 10 Jan. 2008, $2352 \mathrm{~m}$ (MRAC 226757); 1 ô, 26 Jan. 2008 (MRAC 226761); 1 +, 25 May 2008 (MRAC 226750); 1 \&, 10 Sep. 2008

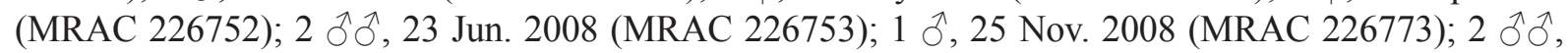
25 Mar. 2008 (MRAC 226764); 1 ô, 10 Oct. 2008 (MRAC 226574); 1 ô, 10 Oct. 2008 (INECN); 1 q, 25 Dec. 2008 (INECN); 1 q, 10 Jul. 2008 (INECN); 5 우, 10 Jan. 2009 (INECN); 7 + , 25 Aug. 2008 (INECN); 2 우, 10 Dec. 2008 (INECN); 8 우, 26 Jan. 2008 (INECN); 2 q $q, 10$ Nov. 2008 (INECN); 4 우우, 25 Oct. 2008 (INECN); 2 웅, 25 Nov. 2008 (INECN); 2 ô $\widehat{o}, 02.87149^{\circ} \mathrm{S}, 029.49641^{\circ} \mathrm{E}$, site 3 , forest with Hagenia abyssinica, 25 Oct. 2008, 2444 m (MRAC 226770); 6 우, 26 Jan. 2008 (MRAC

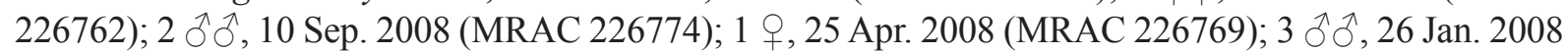
(MRAC 226733); 1 q, 10 Jun. 2008 (MRAC 226751); 1 क, 10 Mar. 2008 (MRAC 226737); 1 ô, 1 q, 3 juvs, 25 Feb. 2008 (MRAC 226739); 1 \&, 25 Nov. 2008 (MRAC 226740); 1 \&, 10 Dec. 2008 (MRAC 226537); 1 +, 10 May 2008 (MRAC 226523); 1 q, 25 Nov. 2008 (MRAC 226529); 1 +, 10 Apr. 2008 (INECN); 1 o, 10 Mar. 2008 (INECN); 1 ô, 25 Jul. 2008 (INECN); 2 우, 10 Apr. 2008 (INECN); 2 우 ㅇ, 25 Aug. 2008 (INECN); 1 ㅇ, 25 Sep. 2008 (INECN); 10 ㅇ, 5 juvs, 25 Feb. 2008 (INECN); 2 우, 10 Sep. 2008 (INECN); 1 , 2 juvs, 10 Aug. 2008 (INECN); 2 우, 25 Jan. 2008 (INECN); 1 , 10 Nov. 2008 (INECN); $2 \partial^{\AA}, 02.87060^{\circ} \mathrm{S}, 029.49669^{\circ} \mathrm{E}$, site 2, forest with Hagenia abyssinica, $25 \mathrm{Aug} .2008$, 2548 m (MRAC 226749); 1 đै, 10 Sep. 2008 (MRAC 226767); 1 ㅇ, 25 Sep. 2008 (MRAC 226742); 1 ô, 10 Sep. 2008 (MRAC 226745); 1 ㅇ, 25 Apr. 2008 (MRAC 226755); 1 + 25 Dec. 2008 (MRAC 226542); 1 ð, 10 Dec. 2008 (MRAC 226570); 1 q, 10 Jan. 2008 (MRAC 226526); 1 đ, 2 juvs, 25 Jul.

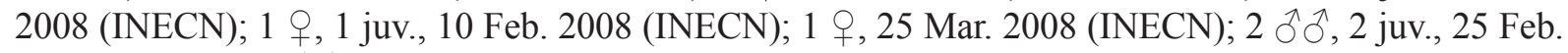

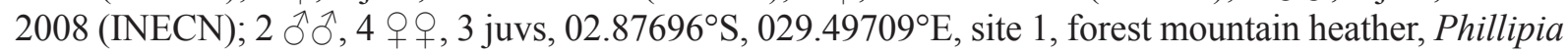

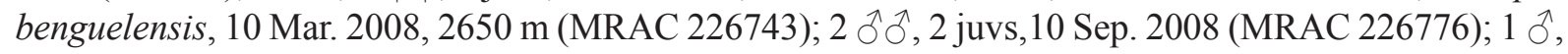




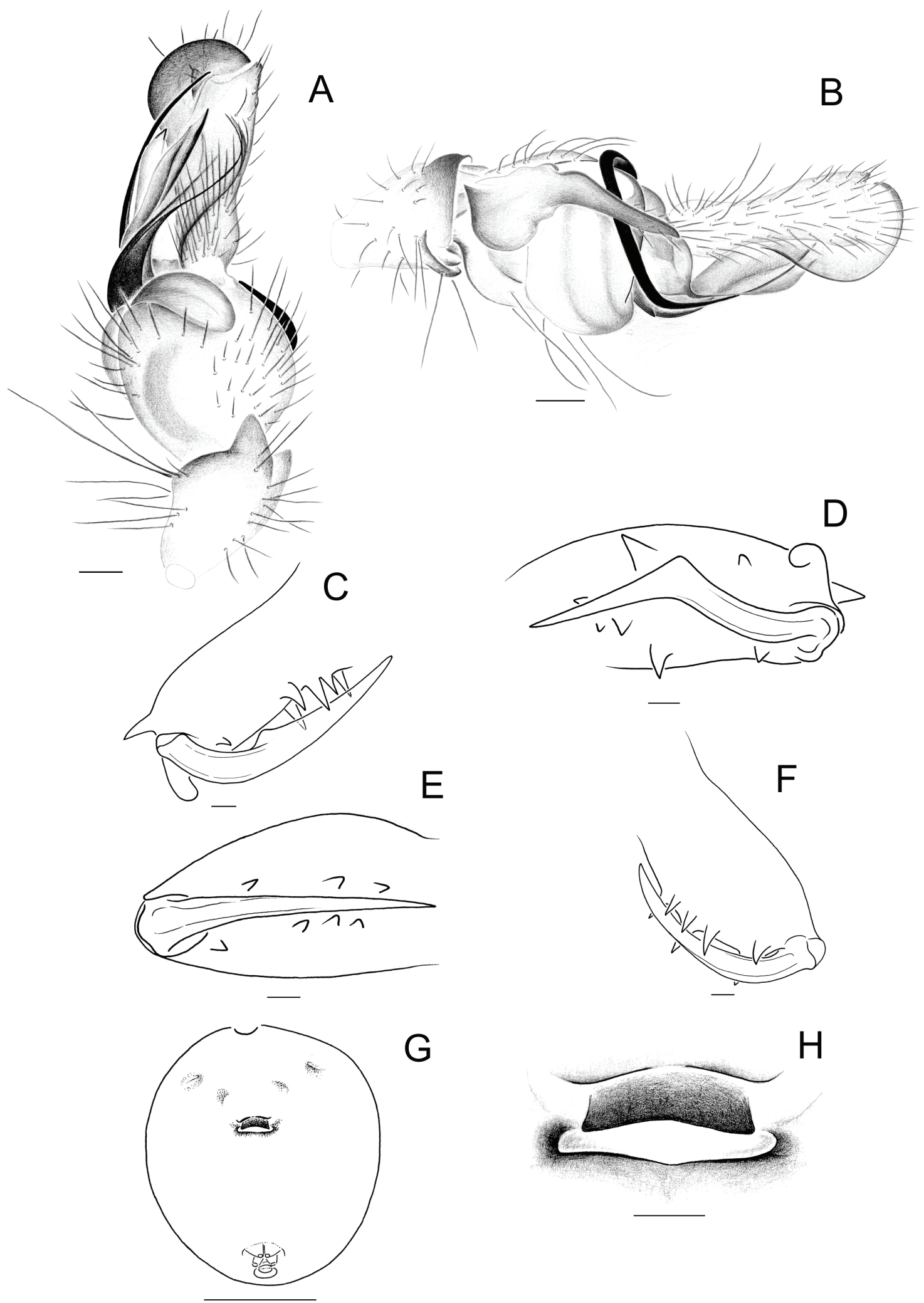

Fig. 4. Pachygnatha ventricosa sp. nov. A. Male palp, ventral view. B. Male palp, retrolateral view. C. Male chelicera, frontal view. D. Male chelicera, ventral view. E. Female chelicera, ventral view. F. Female chelicera, frontal view. G. Female abdomen, ventral view. H. Female external genitalia, ventral view. Scale bars: $A F, H=0.1 \mathrm{~mm} ; G=1 \mathrm{~mm}$. 
10 Jun. 2008 (MRAC 226746); 1 +, 10 Sep. 2008 (MRAC 226759); 3 우, 5 juvs, 25 Mar. 2008 (MRAC 226778); 1 đ, 10 Aug. 2008 (MRAC 226765); 2 우, 25 Feb. 2008 (MRAC 226744); 1 đ, 10 Mar. 2008 (MRAC 226741); 1 ô, 10 Mar. 2008 (MRAC 226712); 2 웅, 10 Mar. 2008 (MRAC 226530); 1 , 25 Nov. 2008 (MRAC 226541); 1 ô, 10 Oct. 2008 (INECN); 1 †े, 10 Nov. 2008 (INECN); 2 우우, 25 Feb. 2008 (INECN); 2 우, 25 Aug. 2008 (INECN); 6 우, 25 Feb. 2008 (INECN); 1 , 25 Jun. 2008 (INECN); 2 우, 10 Jan. 2009 (INECN); 2 우, 25 Mar. 2008 (INECN); 2 우, 10 Nov. 2008 (INECN); 1 , 10 Jun. 2008 (INECN); 1 , 10 Jul. 2008 (INECN); 2 우, 25 Oct. 2008 (INECN); 2 우, 1 juv., 25 Jul. 2008 (INECN); 1 กิ, 10 Jul. 2008 (MRAC 226738).

\section{Description}

Male

Holotype, Figs 1J-L, 4A-D.

MeAsurements. Total length 3.47, carapace 1.67 long, 1.34 wide.

CARAPACE. Pale brown, prominent anteriorly, with a mediodorsal longitudinal dark brown band and two lateral margin dark brown bands.

Eyes. AME: 0.14, ALE 0.12, PLE: 0.12, PME 0.20, AME-AME: 0.04, PME-PME< 0.02, AME-ALE: 0.10, PME-PLE: 0.12, ALE-PLE: 0.00, MOQ: AW: 0.32, PW: 0.38, L: 0.34.

Chelicerae. (Fig. 4C-D). Yellowish brown, three promarginal teeth, three retromarginal teeth, an additional, promarginal cylindrical spur and a sharp apical spur.

STERNUM. Yellowish brown with a sharp sclerotised point at each end of the straight anterior margin; intercoxal sclerites present. Labium brown.

Legs. Yellowish brown; one thin slightly recurved dorsal distal spine on patellae; no further spines.

AвDOMEn. Dorsum pale grey with irregular, connected dark grey spots in almost two longitudinal lines mixed with silvery spots; venter yellowish grey, convex grey line and two silvery spots in two longitudinal lines. Spinnerets pale yellowish brown.
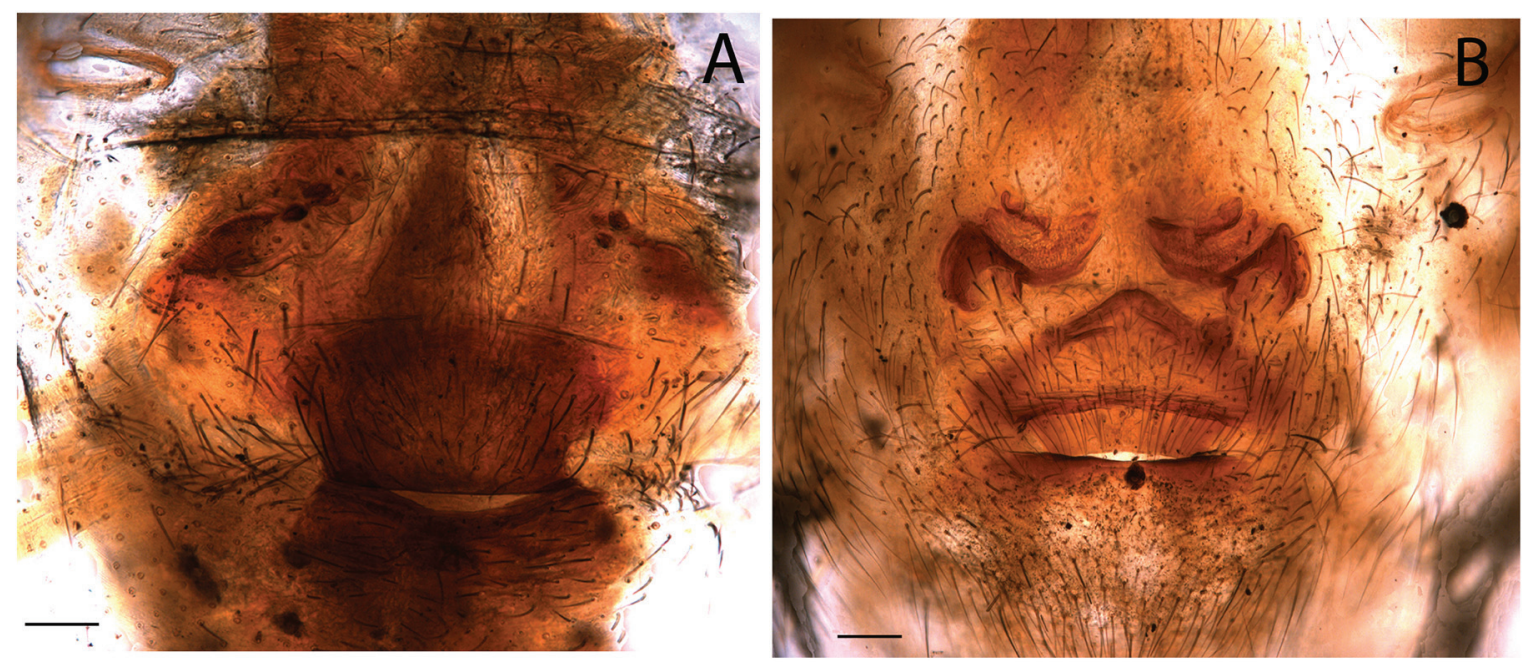

Fig. 5. A. Pachygnatha intermedia sp. nov. Female genitalia, cleared, ventral view. B. Pachygnatha ventricosa sp. nov. Female genitalia, cleared, ventral view. Scale bars $=0.1 \mathrm{~mm}$. 
NZIGIDAHERA B. \& JOCQUÉ R., New Pachygnatha species (Araneae, Tetragnathidae) from Burundi

PALP. (Fig. 4A-B). Retrolateral tibial apophysis sharp at tip, ventral tibial apophysis broad, blade-shaped. Paracymbium long, broad on one side towards the base, with small horn to almost middle part of other side. Embolus long, running spirally to the cymbium tip, supported by conductor.

LEG MEASUREMENTS

\begin{tabular}{|c|c|c|c|c|c|c|}
\hline Leg & Fe & Pa & T & Mt & t & Total \\
\hline I & 2.28 & 0.60 & 0.40 & 2.00 & 1.00 & 6.28 \\
\hline II & 2.08 & 0.60 & 2.12 & 1.80 & 0.80 & 7.4 \\
\hline III & 1.36 & 0.52 & 1.20 & 1.08 & 0.52 & 4.68 \\
\hline IV & 2.40 & 0.48 & 1.76 & 1.76 & 0.68 & 7.08 \\
\hline
\end{tabular}

Female

Paratype, MRAC 226536, Figs 1M-O, 4E-H, 5B. Very similar to male.

Measurements. Total length 4.32. Carapace 1.72 long, 1.36 wide.

Eyes. AME: 0.14, ALE: 0.12, PME: 0.20, PLE: 012, AME-AME: 0.06, PME-PME: 0.02, ALE-PLE: 0.00, AME-ALE: 0.10, PME-PLE: 0.12; MOQ: AW: 0.40, PW: 0.32, L: 0.40.

Chelicerae. (Fig. 4E-F). Yellowish brown, 3 promarginal teeth, 3 retromarginal teeth, both margins with short, sharp distal spur.

LEGS. With some vague grey spots on articulations of femora and patella and the tip of tibia; one spine on patella.

External genitalia. (Figs 4G-H, 5B). A simple, horizontal slit with an inferior part highly sclerotised laterally, superior one blade-shape and connected to inferior one by hyaline extension in two extremities; a sclerotised fold along the superior part.

LEG MEASUREMENTS

\begin{tabular}{|c|c|c|c|c|c|c|}
\hline Legs & Fe & Pa & T & Mt & t & Total \\
\hline I & 2.40 & 0.68 & 2.80 & 2.12 & 1.00 & 9.00 \\
\hline II & 2.20 & 0.68 & 2.16 & 1.80 & 0.88 & 7.72 \\
\hline III & 1.48 & 0.52 & 1.16 & 1.12 & 0.56 & 4.84 \\
\hline IV & 2.12 & 0.48 & 1.80 & 1.72 & 0.52 & 6.64 \\
\hline
\end{tabular}

\section{Other material examined}

BURUNDI: 1 q, Kibira National Park, Rwegura, forêt de Rwegura, $02.89891^{\circ} \mathrm{S}, 29.50405^{\circ} \mathrm{E}$, site 1 , tea plantation, 30 Sep. 2004, 1970 m, pitfalls, B. Nzigidahera (INECN); 1 त, same locality, 28 Feb. 2005 (MRAC 227618); 2 우, 1 juv., same locality, $02.89565^{\circ} \mathrm{S}, 029.50345^{\circ} \mathrm{E}$, site 2 , forest with Polyscias fulva and Macaranga neomildbraediana, 30 Sep. 2004, $2120 \mathrm{~m}$ (INECN); 2 우, same locality, $0289562^{\circ} \mathrm{S}$, $02950221^{\circ} \mathrm{E}$, site 3, forest with Polyscias fulva and Hagenia abyssinica, 15 Mar. 2005, $2160 \mathrm{~m}$ (MRAC 227616); 1 , same locality, $02.90249^{\circ} \mathrm{S}, 029.51345^{\circ} \mathrm{E}$, forest with Macaranga neomildbreadiana and Xymalos monospora, 26 Jul. 2003, 2223 m (INECN).

\section{Distribution}

Known only from the type locality. 
Pachygnatha procincta Bosmans \& Bosselaers, 1994

Fig. 6

\section{Material examined}

BURUNDI: 1 ${ }^{\wedge}$, Kibira National Park, Rwegura, Mt. Musumba, $02.86^{\circ} \mathrm{S} 29.50^{\circ} \mathrm{E}$, site 7 , tea plantation, 10 Dec. 2008, 2100 m, B. Nzigidahera (MRAC 226772).

\section{Remarks}

The specimen was compared to the holotype from Cameroon (MRAC 202728) and to the specimens from two localities in Kenya (MRAC 111873, MRAC 112015), that were attributed to the same species by Bosmans \& Bosselaers (1994). Reexamination confirms the close resemblance between all these specimens in which the males are characterized by the shape of the paracymbium. This sclerite has a very typical comma shaped bald retrolateral area. The cheliceral dentition of the specimens is virtually identical. The Burundian specimen has a slightly different colouration in the sense that it is paler and less orange than the other specimens. The presently known distribution is shown in Fig. 6.

\section{Discussion}

This study is a result of the intense sampling campaign of ground spiders carried out in the forest ecosystems of Western Burundi during several years (2003, 2005, 2008). Pachygnatha ventricosa sp. nov. was found only in the afromontane forest of the Kibira National Park whereas Pachygnatha bispiralis sp. nov. and P. intermedia sp. nov. were collected there and in the circum-Guinean forest of Kigwena at lower altitude. According to our study, 4 species of Pachygnatha are found in this small part of the Albertine Rift which corroborates the conclusion of Nzigidahera \& Jocqué (2009). They observed

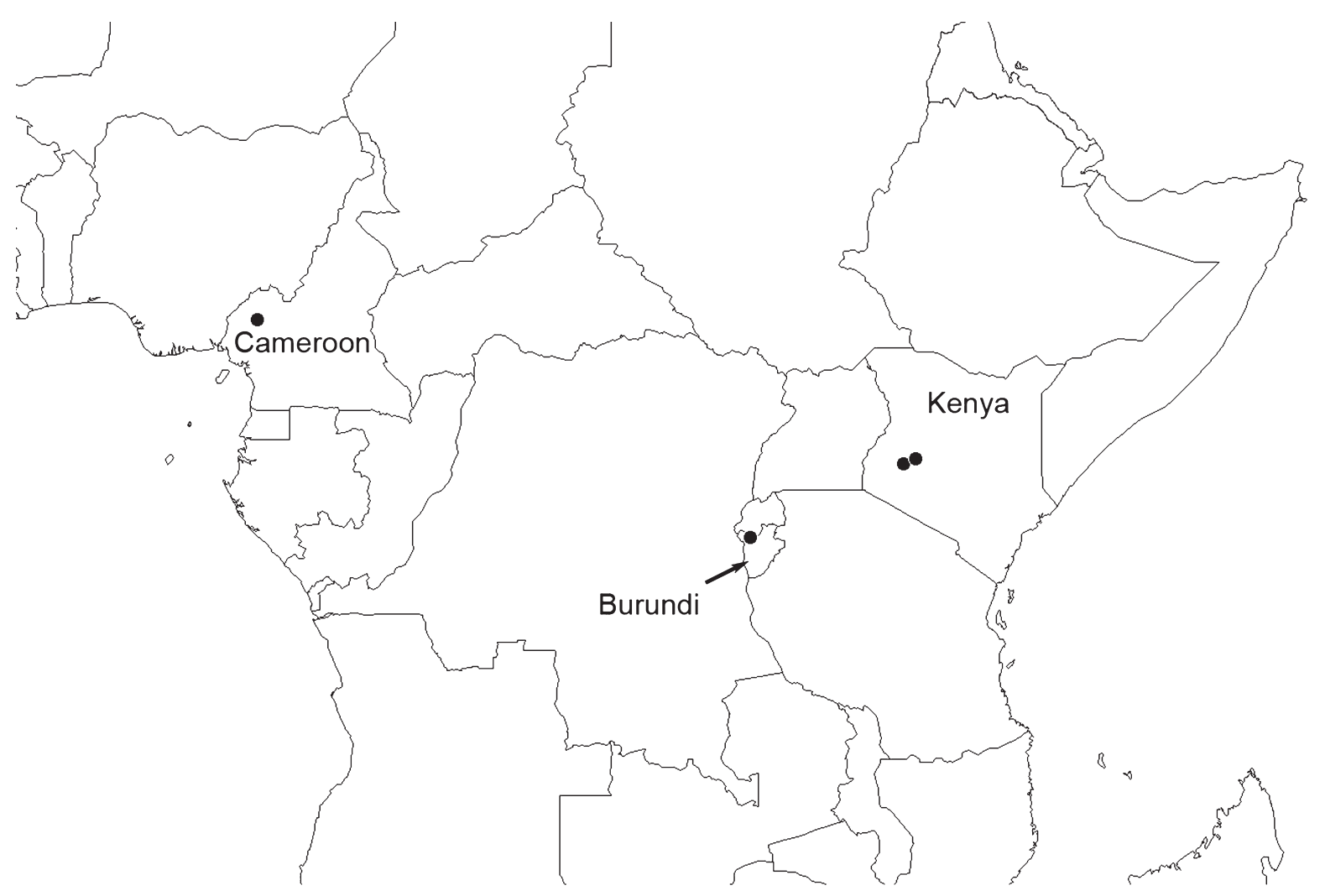

Fig. 6. Distribution map of Pachygnatha procincta Bosmans \& Bosselaers, 1994. 
Table 1. Altitude distribution of Pachygnatha Sundevall, 1823.

\begin{tabular}{|l|l|l|c|}
\hline \multicolumn{1}{|c|}{ Species } & \multicolumn{1}{c|}{ Authorship } & \multicolumn{1}{c|}{ Country } & Altitude \\
\hline atromarginata & Bosmans \& Bosselaers, 1994 & Cameroon & 1600 \\
\hline bispiralis & Nzigidahera \& Jocqué sp. nov. & Burundi & $793-2650$ \\
\hline goedeli & Bosmans \& Bosselaers, 1994 & Cameroon & $>2200$ \\
\hline hexatracheata & Bosmans \& Bosselaers, 1994 & Cameroon & $>1300$ \\
\hline intermedia & Nzigidahera \& Jocqué sp. nov. & Burundi & $793-2650$ \\
\hline jansseni & Bosmans \& Bosselaers, 1994 & Cameroon & $>1200$ \\
\hline kiwuana & Strand, 1913 & Congo & $>1463$ \\
\hline leleupi & Lawrence, 1952 & Cameroon & $>1200$ \\
\hline longipes & Simon, 1894 & Madagascar & sea level \\
\hline mucronata & Tullgren, 1910 & Tanzania & $>2000$ \\
\hline okuensis & Bosmans \& Bosselaers, 1994 & Cameroon & $>2400$ \\
\hline opdeweerdtae & Bosmans \& Bosselaers, 1994 & Cameroon & $>2200$ \\
\hline palmquisti & Tullgren, 1910 & Tanzania & $>2300$ \\
\hline procincta & Bosmans \& Bosselaers, 1994 & Cameroon & $>2100$ \\
\hline ruanda & Strand, 1913 & Rwanda & 1800 \\
\hline ventricosa & Nzigidahera \& Jocqué sp. nov. & Burundi & $1970-2650$ \\
\hline zappa & Bosmans \& Bosselaers, 1994 & Cameroon & 1900 \\
\hline
\end{tabular}

that this Central African mountain range, recognized as a hot spot for many animal groups, also harbors a high diversity of spiders often belonging to a particular genus which prompted the term 'species swarm'. In their study on the gnaphosid genus Zelotibia Russell-Smith \& Murphy, 2005, RussellSmith \& Murphy (2005) found that no less than 19 species are known from the area. This is therefore the first African area for which there is evidence from the spider fauna that it deserves the epithet "hot spot". Other recent papers on the fauna of the area pointing in the same direction are those on the gnaphosid Zelowan Murphy \& Russell-Smith, 2010 (Murphy \& Russell-Smith 2010), on zodariids (Nzigidahera \& Jocqué 2010a, 2010b) and linyphiids (Nzigidahera \& Jocqué 2014). These studies also suggest that the Albertine Rift is far from completely inventoried and several papers concerning its spider fauna are in preparation.

The genus Pachygnatha has a remarkable distribution on the African continent. All the species have been found above $1200 \mathrm{~m}$ (see Table 1) apart from a few specimens of the new species P. bispiralis and $P$. intermedia, which are common around $2000 \mathrm{~m}$ and higher but were also collected near $800 \mathrm{~m}$. Pachygnatha thus appears to be a common element of the Afromontane spider fauna but had not yet been recognized as such. Moreover, it is a typical case of a template genus with very stable somatic characters but with a large range of secondary sexual characters, more precisely of the male palp and the dentition of the chelicerae. A more extensive study of the genus may therefore yield insights into the evolution of secondary sexual characters and their link with biogeographical distribution.

\section{Acknowledgements}

ABIC (African Biodiversity Information Centre) and GBIF are thanked for several travel grants to (BN). We are indebted to the Royal Museum for Central Africa for accommodation for $\mathrm{BN}$ during his studies in Belgium. We thank also Alain Reygel, who made the drawings with his usual skill. Jan Bosselaers is thanked for his comments on a draft of this paper. 


\section{References}

Bosmans R. \& Bosselaers J. 1994. Spiders of the genera Pachygnatha, Dyschiriognatha and Glenognatha (Araneae, Tetragnathidae), with a revision of the Afrotropical species. Zoologica Scripta 23 (4): 325352.

Murphy J.A. \& Russell-Smith A. 2010. Zelowan, a new genus of African zelotine ground spiders (Araneae: Gnaphosidae). Journal of afrotropical Zoology 6: 59-82.

Nzigidahera B. \& Jocqué R. 2009. An update of Zelotibia (Araneae, Gnaphosidae), a spider genus with a species swarm in the Arbertine Rift. ZooKeys 13: 1-28. http://dx.doi.org/10.3897/zookeys.13.145

Nzigidahera B. \& Jocqué R. 2010a. On new species of Microdiores (Araneae, Zodariidae) from Central and East Africa. ZooKeys 48: 11-19. http://dx.doi.org/10.3897/zookeys.48.411

Nzigidahera B. \& Jocqué R. 2010b. Two new species of Cydrela (Araneae, Zodariidae) extending the distribution of the genus into central Africa. Zootaxa 2578: 62-68.

Nzigidahera B. \& Jocqué R. 2014. On the Afrotropical genus Holmelgonia (Araneae, Linyphiidae), with the description of three new species from the Albertine Rift. European Journal of Taxonomy 77: 1-18. http://dx.doi.org/10.5852/ejt.2014.77

Platnick N.I. 2014. The world spider catalog. Version 10.0. American Museum of Natural History. Available from http://research.amnh.org/iz/spiders/catalog/ [accessed 20 Jan. 2014]

Renner F. 1988. Liste der im Krieg vernichteten Typen des Königlichen Naturalienkabinetts in Stuttgart. In: Haupt J. (ed.) XI Europäisches Arachnologisches Colloquium: 319-329. TUB-Dokumentation Kongresse und Tagungen 38, Technische Universität Berlin, Berlin.

Russell-Smith A. \& Murphy J.A. 2005. Zelotibia, a new zelotine spider genus from central Africa (Araneae, Gnaphosidae). Journal of Afrotropical Zoology 2: 103-122.

Manuscript received: 18 April 2014

Manuscript accepted: 16 June 2014

Published on: 13 August 2014

Topic editor: Koen Martens

Desk editor: Charlotte Thionois

Printed versions of all papers are also deposited in the libraries of the institutes that are members of the EJT consortium: Muséum National d'Histoire Naturelle, Paris, France; Botanic Garden Meise, Belgium; Royal Museum for Central Africa, Tervuren, Belgium; Natural History Museum, London, United Kingdom; Royal Belgian Institute of Natural Sciences, Brussels, Belgium; Natural History Museum of Denmark, Copenhagen, Denmark. 